\title{
Crossing Borders in Irish Drama and Theatre. Art, Artist and Sacrifice
}

\author{
Csilla BERTHA \\ University of Debrecen (Hungary) \\ Institute of English and American Studies \\ csillabertha@gmail.com
}

\begin{abstract}
Among the infinite variety of borders crossed in the theatre - social, national, cultural, gender, generic, aesthetic, existential, and many others this essay focuses on self-reflexive border-crossings in Irish kunstlerdrama (artist-drama) and theatre. Spanning over eighty years, in selected plays from W. B. Yeats's The King of the Great Clock Tower (1934), through Brian Friel's Faith Healer (1979), Frank McGuinness's The Bird Sanctuary (1994) and Marie Jones's Stones in His Pockets (1999), to Enda Walsh's Ballyturk (2014), a few forms of theatrical representation of transgressing and/or dissolving boundaries are explored while attempting to delienate which borders need to be respected, which contested, abolished, and then which to be transcended. Artist figures or artworks within drama, embodying the power to move or mediate between different realms of reality, including art and nature, stage and auditorium, life and death, reveal that sacrificial death proves crucial still in a non-sacrificial age, in enabling the artist and/or instigating spiritual fertility. In addition to his/her role, function, potential in affecting social and spiritual life, the representation of the artist necessarily reflects on theatre's art seeking its own boundaries and opening itself to embrace the audience.
\end{abstract}

Keywords: art, artist, death, sacrifice, self-reflexivity.

Theatre as an art of transformation, by its very nature, continuously practises border crossings - dissolving or transgressing, transcending or violating borders, marking or blending them, making them perceivable or hiding them. Entering the stage itself may be regarded as the greatest border-crossing in the theatre: the actor appearing on stage transforms physical place into theatrical space - as illustrated by Peter Brook's man who creates a theatrical event just by walking across an empty space whilst someone else is watching $(1968,7)$. The insideoutside dialectic lies, according to theatre semioticians, "at the very heart of theatrical semiosis" (McAuley 1999, 23). Theatre is the space of liminality, that is, of crossing thresholds, and the aesthetics of the performative "transforms borders into thresholds [... so it] allows for an art of passage” (Fischer-Lichte 2008, 205). 
If all the world's a stage - then all the world's a border-crossing. Of course, there is no point in discussing theatrical border-crossing in such a broad sense. But the inside-outside division and its representation in the theatre is, indeed, fruitful in identifying the basic forces in a play, whether represented by physical divides on stage (emphatic doors, windows, thresholds) or remaining metaphorical and ambiguous.

In order to consciously cross boundaries, they first must be recognized and acknowledged as existing, and the reverse is also true: any attempt at, or insistence on, border crossing only confirms their existence, acknowledges their significance and marks their location. Questions to be asked concern the forms of theatrical representation of transgressing and/or dissolving boundaries. And also: which borders need to be respected, contested, abolished, and then which to be transcended? Which remain borders and which transform into thresholds? Among the infinite variety of borders crossed or dissolved - social, national, cultural, gender, generic, aesthetic, existential, and many others - I wish to focus on self-reflexive border-crossings in Irish kunstlerdrama (artist-drama) and theatre - without dwelling on the well-theorized relation between drama and theatre. ${ }^{1}$ To explore how artist figures or artworks embody the potential or the power to move or mediate between different realms of reality, including art and nature, stage and auditorium, and the existential borderline between life and death. Death in all the plays I have selected to examine proves to be sacrificial in one way or another - whether it is self-sacrifice or sacrificing others. Sacrifice, this sharpest of border-crossings, has been a crucial element in both tragedy and comedy from the ancient Greeks to the present, as Gary Day asserts in The Story of Drama (2016). As in ancient and classical religious beliefs, and then in Christianity, the dying and resurrecting gods/God fertilize/s the life of the community, so the appeal of sacrifice in the contemporary world is that it "holds out the possibility of giving meaning to death in a culture which would rather not talk about it [...] a meaning to death that has a life-enhancing effect" (Day 2016, 9). In the kunstlerdrama sacrifice is frequently related to the artist figure even in today's secularized world. The representation of the artist and his/her art necessarily also reflects - in addition to his/her role, function, potential in affecting social and spiritual life - on theatre's art seeking its own boundaries and opening itself to embrace the audience.

Irish drama and theatre have often been criticized for being extensively verbal, still dominated by text, even at the time when in theatre art elsewhere visuality

1 While being aware of the crucial differences between the two forms of art, drama and theatre, the written text and the performance text, and that postmodern and postdramatic theatre primarily define themselves in opposition to the dominance of verbality in meaning-making, I believe that the written text, including didascalia, information and descriptions, can create in the "eye of the mind" (W. B. Yeats's phrase) the/a stage performance. This makes it possible to write about a play even without seeing a certain performance which, obviously, is only one interpretation and vision of the play. 
and performativity were taking over the leading role. For example, Anna McMullan in 1996 observes that the Irish theatre tradition of the past hundred years is "usually perceived, as in its total reliance on text, and its avoidance or insulation from the performative experiments of twentieth-century theatre" (qtd. in Wallace 2006, 13). I hope my examples will show that, belying such views, from Yeats's theatrically innovative, avant-garde, symbolic, "total” theatre on to the present, playwrights have successfully engaged with various experimental dramatic and theatrical practices within and without more traditional forms. Theatrical elements associated with postmodernist and postdramatic theatre such as fragmentation, denarrativization, deconstruction, freeplay, role-playing, masks (physical or metaphorical), repetition, and performance of every kind entered the theatre although these in Irish drama and theatre are frequently not used to deconstruct identity or entirely abolish character. Altogether, the distrust of meaning and signification and the elimination of character in Irish theatre is less pronounced than prominent theatre theories suggest (e.g. Pavis 1992, Fuchs 1996), and even at the end-of-the-twentieth century's turn to the supremacy of the subversive power of non-verbal sign-systems, words have not lost their communicative value, dialogues can still strongly participate in meaning-making, along with the magic power of playing with words.

Thus, together with Christopher Murray and Clare Wallace, I would assert that in Ireland the division has never been too sharp, the wall never too solid between modernism and postmodernism in the theatre; "postmodernism does not seem to be acceptable as any kind of new orthodoxy" (Murray 1998, 48), nor have "posthumanist ideas been [...] successfully normalized or universally accepted. Rather, [...] the modern and postmodern coexist" in various configurations (Wallace 2006, 38).

\section{W. B. Yeats, The King of the Great Clock Tower}

Some of the most spectacular dramatized border-crossings occur in Yeats's The King of the Great Clock Tower (1934). In this symbolic, stylized, mythic play set in a King's palace in a no-place at a time defined only as close to midnight, a fairytale-like triangle and clash is acted out. A Stroller arrives who wants to see the Queen and prophecies that she will dance for him and for him alone, then he will sing to her for which she will kiss his mouth. Naturally, this outrages the King and he has the Stroller beheaded. After which the prophecy will be fulfilled.

The play reflects the "stranger-in-the-house" dramatic pattern, traditional in Irish drama since the first decades of the Irish Renaissance, in which a stranger enters the home of a family, a country cottage or a pub, changes the temperature, the 
climate, stirs and often disrupts the life of those inside. This kind of transgression of borders takes a violent but very stylized, avant-garde form in The Clock Tower.

When the stage curtain rises, an "inner curtain," "a drum and gong" become visible on the otherwise empty stage, immediately drawing attention to the play's self-reflexive theatricality: the "Attendants," who will play the role of chorus, will introduce and close the performance inside. The Queen is sitting, wearing "a beautiful impassive mask," the Stroller arrives wearing "a half-savage mask" (Yeats 1952, 633). The greater the contrast between the visual images of the two, the higher the border, and the more audacious - and more mysterious - the transgression. The more spectacular their uniting.

In the opening scene the King reproaches his Queen for her silence: "Why sit you there, / Dumb as an image made of wood or metal, / A screen between the living and the dead?" (Yeats 1952, 634). In these first words he defines her as statue-like, as an image of art at the borderline between the living and dead, where she will actually move when she becomes animated by the appearance of the Stroller's severed head. In contrast to the fact-hunting, authoritative King, the Stroller-Poet insists on the Queen's image that he has created in his head. Although in reality he finds the Queen less desirable than what he had imagined, he continues unshaken, praising the beauty of her image. The created image is superior to kings and all their armed servants, and has its own life, which the visible world does not have to justify or validate.

The Stroller-Poet's belief in the power of imagination is fully revealed in the scenography. Yeats's drama seems to carry out the "inter-art turn" almost singlehandedly in the early-twentieth century Irish theatre. He invented what theoretician Ulla-Britta Lagerroth, talking about interart relations in the theatre, calls the "language of the re-theatricalized theatre, a language [...] of space and scenography, of body and choreography, of light and music. This re-theatricalized language invades the dramatic text, where it takes over the function of dialogue and monologue" (1999, 211-212). And, she goes on saying that "simultaneously with the establishment of the modern theatre language [...] the theatre of silence" is being shaped $(1999,211)$.

Except that Yeats never approaches the new theatrical language from the aspect of Modernism's crisis of dramatic language, since the special Irish relation to language and his, the poet's cherishing the magic power of words would not allow him to silence them in the theatre. In The Clock Tower, along with all the visual, acoustic and kinetic elements of theatricality, words remain an indispensable part of self-expression, communication and sense-making. The whole play is written in verse, with "distinctive rhythms" used "to characterize the two men: the King's verse is full of heavy stresses and is sharply emphatic [... while] that for the Stroller is light, mellifluous and flowing, raising at times to a quiet ecstasy" (Cave 1997, 363). Meaning is created in the heterotopic space of the theatre within, and in the tension between, the different forms of art and communication. 
The life-and-death border-crossing is made visible when the Stroller's severed head is brought on stage. The Head interacts with the Queen in almost mystical ways, symbolized in spoken and sung words, ritual gestures and movements. The Queen's climactic dance for the severed head on the most obvious level enacts the sexual encounter between man and woman. But its meaning may be extended, as, for instance, Shantosh Pall's reading from an Oriental (Indian) perspective shows: dance for Yeats, she argues, "is the rhythm of the universe, cosmic and microcosmic both" $(1976,113)$, and "transcendent reality becomes immanent in the movements of the dancer" $(1976,126)$. The dance symbolizes the uniting of soul and body, the physical and the spiritual, the dead and the living. That is one of those Yeatsean moments when "Unity of Being" is achieved. Where creation becomes possible.

The pitiful King with his wordly, temporal power is left out of this union. As usual in Yeats's plays, archetypal figures form pairs of antinomies: the King, the representative of rational, earthly power becomes opposed to the irrational, passionate, intuitive and enigmatic artist-figures now united, the Queen and the Stroller-Poet. Or, in other words: the world of Time (King of the Clock Tower) and timelessness (immortalized Poet).

The play concludes with the apotheosis of art and artist. The Poet-Stroller, able to step over earthly and existential boundaries, will triumph, thanks to his willing self-sacrifice. A direct contrast to the King who keeps trying to dominate. The severed head (the image itself refers to Irish mythology) of the Stroller, like the dying and resurrecting Dionysos, Zarathustra, the Romantic hero-poet, reaches the Nietzschean "tragic joy" culminating in his/its triumphant singing and the Queen's dancing for him and then kissing him. ${ }^{2}$ The whole scenography (symbolic colours, masks, ritualistic movements, singing, dance) together makes possible the enacting of the mystery that through death - moreover, through suffering murder - the poet-hero achieves spiritual regeneration. It is also the ritual "going to hell" of the artist, as in the Hungarian folk song: "He who wants to be a piper / must go down to hell / That's where he has to learn / How to play on the pipe."

In the severed head's enigmatic song the border-crossing that has been acted out is now confirmed in words: from the perspective of the dead all mortals are only shadows. But the encounter between those on the two sides is a miracle: "What marvel is / Where the dead and living kiss?" - which happens as the Queen kisses the lips of the head at the dividing and connecting moment of night and day, old and new, at the last stroke of the "Clock tolling midnight" (Yeats 1952, 640).

The final tableau, one of the several embeddings of frozen scenes to heighten the significance of the moment, demonstrates the "conceptual base of dance in

2 As Nietzsche looked to art for meaning at the time of "the spiritual impoverishment of late nineteenth-century Europe” (qtd. in Day 2016, 16), so Yeats, greatly inspired by Nietzsche, created many of his tragic heroes and artists as self-sacrificial figures. 
India, equipoise of [...] opposites," the basis of all Oriental aesthetics (Pall 1976, 118). But, as usual, Yeats Westernizes the Eastern concepts and dramatic features: here not simply the pair of antinomies, but also a triangle find balance. This final tableau speaks for itself: the King (after attempting to stab the Queen) is subdued, "kneels, laying the sword at her feet" (Yeats 1952, 640) and begs admittance to the circle with the Stroller's severed head lifted up high by the Queen. Yet this frozen image, followed by the Queen's enigmatic last appearance "framed in the half-closed curtains" (Yeats 1952, 641), looking out at the audience as if on the threshold, keeps ambiguities alive, while gesturally connects stage and auditorium. As Richard Cave, the director of a 1977 London performance of this very rarely produced play suggests, in this "dramatized metaphor," this "openended dramatic conceit" it remains undecidable whether the King's attitude expresses reverence or exhausted defeat, if he has achieved self-discovery, or is destroyed, if the Queen has triumphed at the cost of both men, or which of the three has achieved transcendence through emotional fulfilment $(1997,364)$. Beginning with a still stage image and ending with a similarly still but now pregnant-with-meaning image, with coming to life, violence, ecstatic dance and miraculous singing of a severed head in between, the play turns full circle and yet keeps the boundaries open to the continuation of the cyclical movement.

\section{Frank McGuinness, The Bird Sanctuary}

Obviously, artist-protagonists in contemporary plays are never so heroic. Yet in Irish drama many still keep some of their Romantic-Modernist qualities. Such is the painter Eleanor in Frank McGuinness's The Bird Sanctuary (1994), who possesses, if not quite such magic power as Yeats's poet, then a capability for exercising black magic.

The setting stresses the artist's liminality: Eleanor's home on the edge of the sea in a Dublin suburb, physically and culturally lies on the borderline between city and country, earth and sea, her family a mixture from the East and West (of Anglo-Irish and Irish origins). Yet her home and family form a centre in this liminality, an anchor, a place to belong without which she would lose her creativity. The basically naturalistic milieu created, rife with family conflicts, is unexpectedly broadened to include a fantastic dimension: when it proves to be the price of preserving Eleanor's independence and prospects of creating art, she carries out a long-distance murder through witchcraft. A sacrifice on the altar of her art. Although the sacrificial victim is never seen or heard on stage, only appearing in references, the easy association of the artist's creative energy with her ability to kill is "unsettling" (Lojek 2004, 135). Embedding black magic, the carnivalesque within naturalism obviously destabilizes borderlines, transgresses 
genre-, aesthetic-, dramatic-style boundaries, pulls down walls between different forms, qualities, concepts of space and ontological states.

The Romantic notion of the artist being both "seer and destroyer," able to evoke "chthonic forces" (Murray 2010, 75), receiving divine inspiration - but also conversing with supernatural evil forces, in Irish culture goes back to the ancient satiric poets who could not only bless but also curse. McGuinness's witchlike figures are usually revealed in their dangerous potential but then, by the play's conclusion, their creative and/or healing power comes to prevail. As if moving from the pagan, demonic wild excesses towards deeper humanism impregnated by the Christian law of love and peace.

Paintings interacting with humans participate in the dual process of marking and dissolving boundaries between art and life. Two different kinds of artwork appear onstage: the first is three realistic family portraits visible from the beginning that are part of Eleanor's self-imposed task to preserve the family. But in the play's final tableau the subjects of the paintings are repeated by the characters in the foreground who inadvertently take up the postures of those in the pictures in a mise-en-abyme - if not a réduplication répétée, it is at least a réduplication simple (in Lucien Dällenbach's phrase, 1977, 52). Art transcends its division from life and thus facilitates reconciliations within the family, while also enhancing the theatricality and self-reflexivity of the play (and, at the same time, playfully enacting Oscar Wilde's idea of life imitating art). It re-territorializes identity through visually confirming both continuity and change, suggesting that identity is still related to origins, family, and place.

Another kind of artwork emerges in the closing scene when a huge image of the bird sanctuary is suddenly revealed in place of the back wall. The dividing wall between nature and human artifice, outside and inside, seaside and house thus melts and transforms into art. This image in a metatheatrical manner, reflects on the two related central issues in theatrical semiosis: the "onstage/offstage dialectic and the complex relationship between the physical or material reality and the fictional, illusory world created in and by it" (McAuley 1999, 23).

Yet the very existence of the bird sanctuary painting, the culmination of the artist's whole oeuvre, the result of three years' secluded work, remains uncertain. The stage directions: "the back wall magically reveals the bird sanctuary" (McGuinness 2002, 342), do not unequivocally make clear if it is a painted wall, a painting framed in the wall or the wall having become transparent, offering the view of the actual bird sanctuary outside. Among the questions raised are once again those concerning artistic imagination, images created in the head: Can a strong imagination alone be regarded as art? A hypnotic power to persuade others to see something that is not there? Do the stage characters perceive it as painting or vision?

Questioning the materiality of the Bird Sanctuary painting turns the realism of the bulk of the play into surrealism. Helen Heusner Lojek brilliantly points out the 
resemblance of this final stage image to René Magritte's La Condition Humaine, in which the landscape seen through a window is depicted in a painting on an easel, and "[p]ainting and landscape merge" $(2011,106)$. In McGuinness's play images and words confirm each other in problematizing the painting's materiality: the two sisters' final words remain almost as enigmatic as the picture's appearance.

ELEANOR: If you look, you'll see. The bird sanctuary. Believe me, you'll see it. Pretend, pretend. Keep the faith, dear sister.

MARIANNE: I do, Eleanor.

ELEANOR: So do I, Marianne. (McGuinness 2002, 342)

Each verb in the dialogue - "believe," "keep the faith," "pretend" - contributes to the indeterminacy. Seeing is believing - but is believing seeing? The words draw attention to the active role of the viewer in the process of reception, inviting the audience to share the vision. The sanctuary entering the house in the painting and/or through the dissolving wall can be read as the interiorization of nature through imagination and/or art. In the image itself but even more in the theatrical moment of the revelation, of the transformation. This transformation becomes one of those moments that Peter Brook talks about that "scorches on to the memory an outline, a taste, a trace, a smell - a picture. It is the play's central image that remains, its silhouette, and if the elements are highly blended this silhouette will be its meaning, this shape will be the essence of what it has to say" $(1968,152)$.

The possibility of the total immateriality of the artwork that the characters and audiences see, of its being solely the magic work of the artistic imagination, conjured up mentally, takes us back to witchcraft. But by now the evil potential of witchcraft has been harnessed into human love and desire to help, make peace, and heal.

Contrary to Fredric Jameson's contention that in the globalized world "no enclaves - aesthetic or other - are left, in which the commodity form does not reign supreme" (qtd. in Achilles 2018, 70), in Irish drama and theatre the protest against that value-system runs high. The artist is urged in vain in The Bird Sanctuary that she should paint nice landscapes of Western Ireland because they sell well. By placing the masterpiece on/in/in place of the back wall and keeping its materiality ambiguous, the whole play juxtaposes the emotional-spiritual value of art to its material worth, asserting that art is not a commodity, not even at the time of the play's gestation, in the 1990s, when Irish society was moving fast upward towards the peaks of the Celtic Tiger. 


\section{Marie Jones, Stones in His Pockets}

Marie Jones's Stones in His Pockets (1999) presents a much more overtly globalized world, in which Hollywood filmmakers intrude into the Irish countryside and turn life upside down in a small Irish village in county Kerry, Ireland's most picturesque, hence most touristy region. - Another stranger-in-the-house pattern, now in a neo-colonial context. - The film-makers use the locals as extras, with American stars, an English director and "ambitious" upstart Irish assistant directors. Mediatization, one of the weapons of globalization, is shown taking possession of people and countries as dangerously as colonization did earlier.

Stones in His Pockets is an especially potent example of how postmodernist theatrical tools can be used not to deconstruct identity, but to expose the disrupting effects of globalization as neo-colonialism with its construction of false identities. That, in turn, may lead back to stabilized identity that is rooted in, and grows from, reality, place, community. However old-fashioned this may sound, it embodies a form of confrontation in the theatre to the established order, which now is not the "master-narratives" (Lyotard 1984) of the nineteenth or twentieth centuries but rather the twenty-first-century's obligatory attack on master-narratives (nation, national culture, faith).

The construction of Irish identity falls into the hands and cameras of the Hollywood film-makers who are powerful enough to tell the locals how to behave, for instance, how to act out Irish peasants. The play exposes the phoniness of the film-to-be, as well as revealing how the locals benefit from it and begin to be corrupted by consumerism.

Like many other American films about Ireland, the one being shot in the play also exploits the romanticizing potential of the country. It presents the Irish through the love story of a poor young peasant and a rich Anglo-Irish landlord's daughter leading to reconciliation between the two classes, national groups, and the promise of happier life to all - full of artificiality and simulacrum. Simulacrum dominates from small details to the whole of the performance. The filmcrew, the story, action, local tragedy - everything is acted out by two Irish actors in the play, stepping in and out of the film-within-the-play, turning from one role to another in seconds. They transgress boundaries of nationality, class, social position, gender, age - and artforms - in a socially oriented examination of the possibilites and potentialities of theatre. Unlike in postmodern drama where the boundaries between actors and their roles, actors and acted, are often blurred and it becomes indeterminable who the figure we see onstage is at any given moment (Kékesi Kun 1998, 141), here the roles are clearly distinguishable. Continuous role-playing, role-changing and medial changing do not denote here the dissemination and malleability of identity. Instead, the multiple masks help to outline the protagonists' identities. And that is where resistance germinates. 
This structure foregrounds and questions the authenticity of representation. Simulacrum, "substituting the signs of the real for the real" - as Baudrillard defines it - "an operation of deterring every real process via its operational double, a programmatic [...] perfectly descriptive machine that offers all the signs of the real" $(1994,2)$, is meant to play on the nostalgia of its viewers. Comic examples abound of creating simulacra of authenticity that may look more convincing than the original, for example, views that the primadonna's false Irish accent will sound authentic since other American films have already popularized it, whereas the cows in the fields nearby don't look "Irish enough." Or, in one of the most amusing scenes the extras are instructed to follow with their eyes the hands of the assistant directors, which stand for the film's absent chief characters approaching each other on horseback:

AISLING: [...] my hand will be Maeve approaching on the horse ... then you will look up and stare at her ...

[...] Simon's hand will be Rory approaching Maeve on the horse. [...]

CHARLIE: So it us lookin' dispossessed at her hand, pretending it's Maeve on a horse lookin' sorry for us. (Jones 1999, 33)

The word "Irish" itself "has become deterritorialized, as Patrick Lonergan contends: "it [...] acts as a brand - a commodified abstraction that gives meaning to its purchaser instead of signifying the physical territory of a nation" (2009, 28 - or its psychological, moral territory. Yet, simultaneously with globalization, a counter-globalizing process begins: a search for a sense of home or place a re-territorialization. To initiate that process in Stones in His Pockets, once again, death becomes necessary. The "dispossessed" protagonists are prompted to resistance by the disaster in the play's "real time" when a local young man, Sean, due to his humiliation by the film-people, walks into the lake and drowns himself with stones in his pockets. His suicide becomes a sacrifice that renews the energy of the "dispossessed" Irish to repossess themselves and prioritize the community's interest. And empowers their efforts to express themselves in creative work - in art.

Bending the weapon of globalizing film-making to their own particularity, the protagonists plan to make their own film, which then will reverse roles. The now extras will move from the periphery to the centre: "the stars become the extras and the extras become the stars. So it becomes Sean's story [...] and all the people in this town" (Jones 1999, 54).

The new film will be called Stones in His Pockets. A Möbius-strip kind of turning inside out the film-making that is dramatized in the play which then becomes the play that we watch. Werner Huber describes this mise-en-abyme with what Lucien Dällenbach identified as a "réduplication aporistique," where 
a part or fragment of the work contains the work that contains it (Huber 2002, 20). The two theatre-actors, impersonating everyone, insiders and outsiders, become the ones who, after all, control and authenticate the whole performance in the theatre through the narrative, the transgressive power of satire, parody, imitation, that is, through performance.

In their own story, neo-naturalism will become a form of resistance: in an attempt at cultural re-territorialization, the Irish will be set in their natural physical environment. Somewhat like the "in-yer-face" radical theatre in England, here Irish reality - instead of American simulacra of painted paperislands - represented by the cows that the hapless young man liked so much will hit the viewers: "all you see is cows, every inch of screen, cows [...] cows, just cows and in the middle of all these trandy designer trainers. [...] sinkin' into a big mound of steaming cow clap [...]. Cows ... big slabbery dribblin' cows. [...] Udders, tailes, arses, in your face. [...] wide shots. Yes, mid shots. Yes. Close ups. Yes” (Jones 1999, 58).

Taking representation into one's own hands promises one way of destabilizing globalization's exploitation and of putting into brackets the whole powerstructure. At least on a cultural level. But, as Declan Kiberd encouragingly suggests, in Ireland culture might be "the one domain in which an unfettered kind of sovereignty might yet be enjoyed” $(2018,23)$.

\section{Enda Walsh, Ballyturk}

Another two-hander, role-acting play, Ballyturk (2014), by the critically acclaimed playwright, Enda Walsh, thematizes death itself most directly and sets it into the centre. A very Beckettian absurd, with strong intertextuality but with Walsh's hallmark of (non-Beckettian) frenetic play-acting, role-changing and selfconscious theatricality. Here even more than in the other plays, all the world is performance. As Estragon and Vladimir try various pastimes while waiting, so Walsh's characters, the nameless 1 and 2, perform. They keep impersonating fictional people whose portraits, drawn by one of them, are visible on the walls thus a many-layered acting and mirroring goes on from images to the invisible fictional characters to the protagonists enacting them as actors.

Once again, curiously enough, the traditional stranger-in-the-house pattern organizes the action in this postmodernist, definitiely non-traditional play: the two figures inside the room keep clowning until, unexpectedly, another figure, called 3, does arrive. Not Godot, but Death in a human form. Or, in Christopher Murray's words: "more a Button-Moulder from a modernized Peer Gynt, a collector of souls" $(2017,27)$. He changes the rules of the game and prompts the characters to enact their own selves, their fears and anxieties. His crossing the 
border between the two sides of existence is rather dramatic and spectacular: he walks onto the stage after the back wall tears away from the side walls and crashes down making a loud noise, opening "out into a beautiful blue light - onto a small hill of green perfect grass" (Walsh 2014, 36). A colourful vision of the other world with serenity and sunshine, yet due to its stark surreality, its effect is far from any postmodern ridiculing or ironizing dreams of the other world.

What is intriguing as a form of theatre is that the frantic, sometimes nervebreaking clowning evoking the "reality" of the village Ballyturk and its inhabitants with no coherent story or plot, gains meaning beyond itself when the actor-figures become humanized and their story begins to take shape. As characteristic of postdramatic theatre, drama's coherence, its developing a narrative is deconstructed, and action is replaced by "states" - as defined by Hans-Thies Lehmann. The "particular dynamic within the 'frame' of the state" he calls "a scenic dynamic, as opposed to the dramatic dynamic" (2006, 68; emphasis in the original). Indeed, the mad role-playing inside the closed room creates a strong scenic dynamic in Ballyturk - but that is not the whole play. Once the back wall opens, the "dramatic dynamic" grows and the postdramatic play begins to acquire coherence. Drama emerges when the actors step out of the "frame" into a theatrical reality. And when they are given emotional and moral dilemmas in the face of death: the Death figure offers them the choice as to which of them will join him. Which, in turn, raises questions, such as what is more difficult, to leave (to die) or to stay alive bereft. Can one save another from suffering by helping him to choose death? Character 2 is at first willing to leave but seeing how No. 1 is frightened at the prospect of being left alone, encourages him to go instead. Self-sacrifice itself obtains a new meaning.

In the last exchanges between the two men birth and death seem to come full circle. Character 2 says: "There was nothing to start with - and out of that me and you pushed words" (Walsh 2014, 50) - a daring claim for creation. "In the beginning was the Word..." in the Bible (John 1:1) - but does Walsh acknowledge that also in the theatre? A rather surprising turn since most of the play communicates not with words but with strong physical theatre. Towards the end of the play the Deathfigure gives a long, philosophical monologue about life and death, concluding that "In leaving you're giving shape to life - some design and purpose for being what you are - for this is the order that all life demands [...] it needs a death" (Walsh 2014, 46). "Giving shape to life" also gives shape to art, to theatre, to the performance that in the end goes ways beyond the re-iterations and re-enactments.

Borders between reality and imagination are again crossed over and over. The overlapping levels of "reality" during the greater part of the play: the visible actors in the room, the villagers whom they act out and who are also represented in the drawings on the wall, turn out to be reduced to one: the imagination of the two protagonists. When the death-figure asserts plainly that "none of it's real," 
then figure 1 protests that "[o]nly inside our heads it is" (Walsh 2014, 44). In contrast, the world outside the room is called real life - from Death's perspective his world is "real:" "Everything you've imagined - it is. All life. It's out there. Everything" (Walsh 2014, 44). The play seems to suggest that the other world is more real than the one we live in where only performance - that is simulacrum, pretension, make-believe - keeps up the dynamics. And if role-acting, play - art - did not help to face the fear of death, sacrifice does - in accordance with Gary Day's claim that sacrifice helps one to cope with the inevitability of death (2016).

The self-sacrifice of figure 2 brings about a renewal or at least a promise of continuation of life: as he looks around him lost, after his friend has left, a young girl enters through the side wall - a new playmate? Someone to look after? Someone to console him? A figure of hope for life going on. Another unexpected breaking through walls, but this from a horizontal, that is human direction, as opposed to the vertical, metaphysical intrusion of the Death figure.

\section{Brian Friel, Faith Healer}

The last play I will address, Brian Friel's Faith Healer (1979) is the least spectacular, the most pared down. It consists of four monologues of three characters, who appear one after the other, there is no dialogue, no encounter at all. And yet it is most theatrical in its poverty of means.

An ironic postmodern variant of Yeats's heroic Stroller-Poet, triumphing through self-sacrifice, the shabby, alcoholic, beggar-like, failing faith healer, Frank Hardy, became probably the most emblematic artist figure in twentieth-century Irish drama. His agonizing over the contradictions of being gifted and cursed by an unusal talent, communicates the artist's - and the playwright's - urgent dilemma of being a true artist or a trickster, a "con-man;" the difference lying in following a certain "standard of excellence" as opposed to seeking the audience's favour. Real faith healing or performance. This extensively verbal play proves an early and very daring experiment with postdramatic theatre. Curiously, it becomes the most intriguingly dramatic through the words and minimal gestures, the presence and the "present of performance" (Lehmann 2006, 141), evoking the intertwined lives and deaths of the three characters.

The monologues of Frank, his wife and his manager confront the audience with versions of the same events, so we are invited to put together the story as best we can from the sometimes contradictory, other times partly or exactly coinciding parts of narratives. The differences and similarities are important markers of the working of memory - hiding, changing, foregrounding or falsifying what happened. Boundaries are crossed in many ways: physically since we hear about the three travelling from village to village in Wales and Scotland in 
attempts at faith-healing (that mostly fail, but then - rarely - do miraculously work) until their final homecoming to Ballybeg, Friel's fictitious emblematic Irish village. Evidently, boundaries between reality and fiction, facts and imagination, truth and falsehood keep being transgressed in the memory-monologues. But the sharpest borderline again is that between life and death. Two of the three characters talking about their own lives, turn out to be dead, and then the dead Frank, the faith healer, comes onto the stage for a second time in the end, to talk about his own death. In a subtle indication of the dissolving borderline between life, death and art, Frank acts out a little gesture that he made on his last night in life: he crumpled up and threw away the only evidence of his miraculous healing, a newspaper-clipping. And he does just that (again), now in front of the audience. Two separate moments in time and two distinct places (the fictional place and the physical stage) are collapsed in this gesture. As well as the two different phases of Frank's life, one on each side of the existential divide.

Thus, Faith Healer displays the most metatheatrical complexities since it performs performance: performs theatrical art itself - partly by way of consisting only of monologues. The monologue itself-according to Anthony Roche - is the most consciously theatrical form of communication. Story-telling, considered a postmodern device of self-expression, is a natural constituent of Irish drama, originating in the strong oral story-telling tradition - even if here the audience is expected to put together the fragmented pieces and versions into a coherent narration. The almost bare stage featuring only a poster and rows of chairs in front of which the monologues are delivered also enhances self-reflexivity, which, in turn, makes the audience "a crucial participant in the faith-healing ritual" (Roche 2011, 158).

The most elaborate and challenging death-scene described is Frank's, in his own relating. He tells the audience how in their last evening together, the three made friends with a few wedding-guests in a pub, and Frank successfully cured the crooked finger of one of them. He knew that they would ask him to also cure their crippled friend, which would remain beyond his power and that this failure will be fatal. Frank's description of his last steps approaching those who will kill him, is an extraordinary evocation of self-sacrifice, ritual elevation and transubstantiation. As for the question of sacrifice for what? for whom? Richard Rankin Russell suggests that in its oblique way it serves the community, deprived of spirituality, especially in the Trouble-torn Northern Ireland of the time. A warning against the savagery of sectarianism, yet "its potentially redemptive conclusion [...] points towards openness and healing beyond the individual tragedies" $(2014,141)$.

Frank's closing monologue vividly evokes the surrealistically formal, symmetrical space of the pub's courtyard where he was called out to heal the crippled man. At dawn, he walked "towards the arched entrance, because framed in it, you would think posed symmetrically were the four wedding guests, and in 
front of them, in his wheelchair, McGarvey.” And although Frank knew he would not be able to cure him, he walked towards them:

And as I walked I became possessed of a strange and trembling intimation: that $[\ldots]$ we had ceased to be physical and existed only in spirit, only in the need we had for each other. [...] And as I moved across that yard towards them and offered myself to them, then for the first time I had a simple and genuine sense of home-coming. Then for the first time there was no atrophying terror. And the maddening questions were silent. (Friel 1984, 375-376)

This transformation, the acting out of approaching certain death in a ritualized space and with ritualized movements goes against rational thinking as strongly as did Yeats's Stroller undergoing execution for holding on to his created image and prophecy. Faith Healer's closing scene magically enabling the artist-figure to create an artistic image of his own death elevates the audience to a community of witnesses or almost-participants in a ritual. And becomes a very complex, ambiguous, yet strong re-confirmation of theatre's power in creating community and asserting spiritual values in the non-spiritual age.

Seamus Heaney's poetic summary rings true even today: "Faith Healer has the radiance of myth, it carries its protagonist and its audience into a realm beyond expectation, and it carries the drama back to that original point where it once participated in the sacred, where sacrifice was witnessed and the world renewed by that sacrifice" $(1993,237)$.

\section{Conclusion}

Read together, these plays appear to outline one stream of Irish drama tradition up to and into postmodernity: taking art and artist very seriously. And, while being aware of the times and theatrical trends, these playwrights do not find it necessary to deconstruct everything and triumph in destruction. It still is possible to keep some traditional values in very modern guises, responding to the times but not being a slave to them. It is no surprise then that Declan Kiberd can say as late as 2018 that in Ireland the only "ethical language available for use in the public sphere" has been employed in the last decades by artists $(2018,18)$ and they, unlike other intellectuals or political leaders, never betrayed public trust, therefore people are still willing "to look to artists for pointers [... and] inspiration" $(2018,22)$.

From Yeats's romantically conceived artist-figure to Friel's self-doubting, rundown, failed faith-healer through McGuinness' painter devoting her art to create a sanctuary for some traditional values: family, home and art, to Jones's hopeless film-extras growing into potential film-makers, the artist still seems to have magic 
powers in Ireland. Creators and destroyers, sacrificing themselves and/or their nearest and dearest, or empowered through someone else's sacrifice, they all seem to serve someone or something beyond their own selves: the community, the prestige of art, or, at least a friend in the most recent of them, Ballyturk, written at the time when communal concerns have been replaced by individual ones. With their metatheatricality all five plays express a belief in the necessity of facing and addressing the inevitable existential borders between life and death, but also in transcending the boundaries between art and life, stage and auditorium, and including the audience as an active partner in the theatrical experience.

\section{Works Cited}

Achilles, Jochen. 2018. "Intermedial Drama and the Commodification of Irish Identities.” In Boundaries, Passages, Transitions, ed. Hedwig Schwall, 77-90. Trier: Wissenschaftlicher Verlag.

Brook, Peter. 1968. The Empty Stage. London: Penguin Books.

Baudrillard, Jean. 1994. Simulations and Simulacra. Trans. Sheila Faria Glaser. Ann Arbor: University of Michigan Press.

Cave, Richard Allen. 1997. "Commentaries and Notes." In W. B. Yeats. Selected Plays, ed. Richard Allen Cave, 362-389. London: Penguin Books.

Dällenbach, Lucien. 1977. Le récit spéculaire: essai sur la mise en abyme. Paris: Seuil.

Day, Gary. 2016. The Story of Drama. Tragedy, Comedy and Sacrifice from the Greeks to the Present. London: Bloomsbury.

Fischer-Lichte, Erika. 2008. The Transformative Power of Performance: A New Aesthetics. Trans. Saskya Iris Jain. London: Routledge.

Friel, Brian. 1984 [1979]. Faith Healer. In Selected Plays, 327-376. London: Faber.

Fuchs, Elinor. 1996. The Death of Character: Perspectives on Theatre after Modernism. Bloomington and Indiana: Bloomington University Press.

Heaney, Seamus. 1993. "For Liberation: Brian Friel and the Use of Memory." In The Achievement of Brian Friel, ed. Alan J. Peacock, 229-240. Gerrards Cross: Colin Smythe.

Huber, Werner. 2002. "Contemporary Drama as Meta-Cinema: Martin McDonagh and Marie Jones." In (Dis)Continuities: Trends and Traditions in Contemporary Theatre and Drama in English, eds. Margarete Rubik and Elke MettingerSchertmann, 13-23. Trier: Wissenschaftlicher Verlag.

Jones, Marie. 1999. Stones in His Pockets. London: Nick Hern Books.

Kékesi Kun, Árpád, 1998. Tükörképek lázadása. A dráma és színház retorikája az ezredvégen. [Rebellion of Mirror-Images. The Rhetoric of Drama and Theatre at the End of Millennium.] Budapest: Kijárat. 
Kiberd, Declan. 2018. “Going Global?” In Boundaries, Passages, Transitions, ed. Hedwig Schwall, 13-24. Trier: Wissenschaftlicher Verlag.

Lagerroth, Ulla-Britta. 1999. "Reading Musicalized Texts as Self-Reflexive Texts. Some Aspects of Interart Discourse.” In Word and Music Studies. Defining the Field, eds. Walter Bernhart, Steven Paul Scher and Werner Wolf, 205-220. Amsterdam: Rodopi.

Lehmann, Hans-Thies. 2006. Postdramatic Theatre. London and New York: Routledge.

Lojek, Helen Heusner. 2004. Contexts for McGuinness's Drama. Washington, D.C.: The Catholic University of America Press.

2011. The Spaces of Irish Drama. Stage and Place in Contemporary Plays. New York: Palgrave Macmillan.

Lonergan, Patrick. 2009. Theatre and Globalization. Irish Drama in the Celtic Tiger Era. Houndsmills, Basingstoke: Palgrave Macmillan.

Lyotard, Jean-François. 1984. The Postmodern Condition: A Report on Knowledge. Trans. Geoff Bennington and Brian Massumi. Manchester: Manchester University Press.

McAuley, Gay. 1999. Space in Performance. Making Meaning in the Theatre. Ann Arbor: University of Michigan.

McGuinness, Frank. 2002 [1994]. The Bird Sanctuary. In Plays 2, 265-342. London: Faber.

Murray, Christopher. 1998. "The Foundation of the Modern Irish Theatre: A Centenary Assessment.” HJEAS vol. 4, no. 1-2: 39-56.

2010. "Joyce, Yeats and The Bird Sanctuary." Irish University Review vol. 40, no. 1: 69-80.

2017. “The Plays of Enda Walsh: An Interim Report.” HJEAS vol. 23, no. 1: 26-27.

Pall, Shantosh. 1976. "The Dancer in Yeats.” STUDIES vol. 65, no. 258: 112-127. Pavis, Patrice. 1992. Theatre at the Crossroads of Culture. Trans. Loren Kruger. London and New York: Routledge.

Roche, Anthony. 2011. Brian Friel. Theatre and Politics. Houndsmills, Basingstoke: Palgrave Macmillan.

Russell, Richard Rankin. 2014. Modernity, Community, and Place in Brian Friel's Drama. Syracuse, NY: Syracuse University Press.

Wallace, Clare. 2006. Suspect Cultures. Narrative, Identity and Citation in 1990 s New Drama. Prague: Litteraria Pragensia.

Walsh, Enda. 2014. Ballyturk. London: Nick Hern Books.

Yeats, William Butler. 1952 [1934]. The King of the Great Clock Tower. In The Collected Plays, 633-642. London: Macmillan. 